\title{
Biogeochemistry of Antarctic sea ice: a case study on platelet ice layers at Drescher Inlet, Weddell Sea
}

\author{
Sven Günther*, Markus Gleitz, Gerhard S. Dieckmann
}

Alfred Wegener Institute for Polar and Marine Research, Postfach 120161, D-27515 Bremerhaven, Germany

\begin{abstract}
Interstitial water samples collected from sea-ice platelet layers at a coastal site in the eastern Weddell Sea, Antarctica, were analyzed for total alkalinity, $\mathrm{pH}_{1}$ major nutrient, oxygen, dissolved inorganic carbon (DIC) concentrations and biomass. Based on the data obtained here and in previous studies on sea-ice ecosystems, a conceptual description of biogeochemical processes during maturation of algal blooms in semi-enclosed sea-ice habitats is presented. The concept invokes an initial phase of nitrate-based 'new' production during which nutrient replenishment from the surrounding seawater surpasses algal demand, leading to rapid accumulation of algal biomass in excess of what is accounted for by the apparent DIC and nutrient depletion. As long as nitrate is present in non-limiting quantities, primary production proceeds in close agreement with Redfield ratios. During later stages of the bloom, algal nutrient demand exceeds replenishment, and nitrate is completely consumed, where the photosynthetic quotient indicates utilization of ammonium. Following nitrate exhaustion, photosynthetic carbon fixation is maintained, but is directed towards production of carbon-rich metabolites and excretion of dissolved organic matter, leading to further DIC drawdown and alteration of algal biochemical composition from the nitrate-replete state. During both phases, cell mortality and lysis in conjunction with inefficient feeding of metazooplankton (if present) lead to liberation and subsequent accumulation of dissolved matter including major nutrients. The co-occurrence of phosphate accumulation, strong oxygen supersaturation and depleted DIC concentration thus suggest that heterotrophic oxidation of organic matter may not represent the major pathway by which nutrients are regenerated in sea-ice ecosystems.
\end{abstract}

KEY WORDS: Antarctic $\cdot$ Platelet ice $\cdot$ Nutrient cycling $\cdot$ Carbon flux $\cdot$ DIC

\section{INTRODUCTION}

During balanced growth, phytoplankton absorb major nutrients and dissolved inorganic carbon (DIC) in stoichiometric quantities known as the Redfield ratios (C:N:P = 106:16:1, Redfield 1958). In biological oceanography, these ratios have been used extensively to model phytoplankton productivity as a function of a limiting nutrient, and to describe ocean biogeochemical cycles (Broecker \& Peng 1982, Falkowski \& Woodhead 1992). In the winter mixed layer of the Southern Ocean, nitrate, silicate and phosphate concentrations of approximately 30,75 and $2 \mu \mathrm{mol} \mathrm{l}^{-1}$ respectively (Jennings et al. 1984, Scharek et al. 1994) could con-

\footnotetext{
•E-mail: sguenther@awi-bremerhaven de
}

vert to maximum phytoplankton standing stocks of about $200 \mu \mathrm{mol}$ particulate organic carbon (POC) $\mathrm{I}^{-1}$ (equals $2400 \mu \mathrm{g}$ (POC) $\mathrm{1}^{-1}$ ) and, assuming a POC to chlorophyll a (chl a) ratio of $50(\mathrm{w} / \mathrm{w})$, a concentration of ca $50 \mu \mathrm{g} \mathrm{chl} \mathrm{al^{-1 }}$ Yet, due to a combination of light, micronutrient, downward export and grazing controls on phytoplankton growth, these values are never attained in the open ocean (Burkill et al. 1995, de Baar et al. 1995).

Antarctic sea-ice biological communities, however, represent a notable exception to conditions observed in the water column. Algal standing stocks $>100 \mu \mathrm{g}$ chl $a 1^{-1}$ have been reported from the bottom part of the congelation ice, from platelet layers, and other habitats closely associated with ice sheets (Palmisano \& Garrison 1993). Apparently, bottom-up and top-down controls constraining phytoplankton biomass accumula- 
tion in the open ocean are at least temporarily ineffective in sea-ice habitats. From a biogeochemical perspective, this observation is remarkable insofar as ice habitats provide the means for phytoplankton to accumulate to concentrations far in excess of maximum standing stocks predicted from complete utilization of major nutrients present in the open water. The obvious explanation is replenishment of nutrients from the surrounding water column, while the aigal cells are retained within the physical boundaries of the habitat due to attachment to ice crystal surfaces, thus preventing a proportional dilution of the algal crop during water exchange.

Rates of exchange with the surrounding seawater can be constrained, however, by density stratification due to meltwater input and the physical barrier imparted by the ice matrix, particularly during the advancing summer season (Dieckmann et al. 1992, Smetacek et al. 1992, Fritsen et al. 1994, Arrigo et al. 1995, Gleitz et al. 1995). Subsequently, ice algal nutrient demand may exceed rates at which nutrients are resupplied, resulting in gradients of dissolved constituents between interstitial waters of ice habitats and the surrounding seawater. When nutrient exchange has completely subsided, algal growth relies on rates of in situ nutrient regeneration. As heterotrophic nutrient remineralization is inevitably associated with a release of dissolved carbon dioxide, in this situation one would not expect to find DIC depletion far in excess of $200 \mu \mathrm{mol} \mathrm{l^{-1 }}$, even if primary production based on regenerated nutrients is sustained. Yet, the few published data on DIC concentrations in sea-ice ecosystems are often at odds with these predictions. Gleitz et al. (1996a) recorded DIC deficiencies of up to $700 \mu \mathrm{mol} \mathrm{l}^{-1}$ in pools of meltwater trapped between melting ice floes. Similar results were also reported from analyses of brine samples collected from intact sea ice during summer (Gleitz et al. 1995). These discrepancies have up to now not been the focus of detailed investigation.

Here we report on a biogeochemical study of interstitial water samples collected from platelet layers at Drescher Inlet, Weddell Sea. Layers of platelet ice are commonly found underlying land-fast and pack ice in coastal regions of the high Antarctic (Ackley \& Sullivan 1994). Ind:vidual ice platelets measure up to several centimeters in diameter, and are up to several millimeters thick. Upon accumulation underneath an existing ice cover, ice platelets consolidate into a more or less rigid lattice that may attain a thickness of up to several meters. In addition to its significance for coastal sea-ice mass balances (Eicken \& Lange 1989), platelet layers have been shown to provide a most favorable habitat for phytoplankton growth (Dieckmann et al. 1992, Smetacek et al. 1992, Arrigo et al. 1993a, Gross- mann et al. 1996). As this semi-enclosed system is comparable with other highly productive sea-ice ecosystems such as meltpools (Gleitz et al. 1996a), freeboard layers (Fritsen et al. 1994) and internal bands of rotten ice (Thomas et al. 1998), it was thus considered a suitable model habitat for a detailed case study of biogeochemical cycles during sea-ice algal blooms.

\section{MATERIALS AND METHODS}

Location of study sites. The study was conducted between 23 January and 23 February 1995 (Julian days 23 to 54 ) at Drescher Inlet, a roughly $20 \mathrm{~km}$ long and 1 to $2 \mathrm{~km}$ wide indentation in the Riiser-Larsen Ice Shelf at $72^{\circ} 52^{\prime} \mathrm{S}, 19^{\circ} 25^{\prime} \mathrm{W}$ (Vestkapp, Eastern Weddell Sea, Antarctica; Fig. 1) half way between the Antarctic Stations Neumayer (Germany) and Halley Bay (UK). The inlet was completely covered by fast ice during the
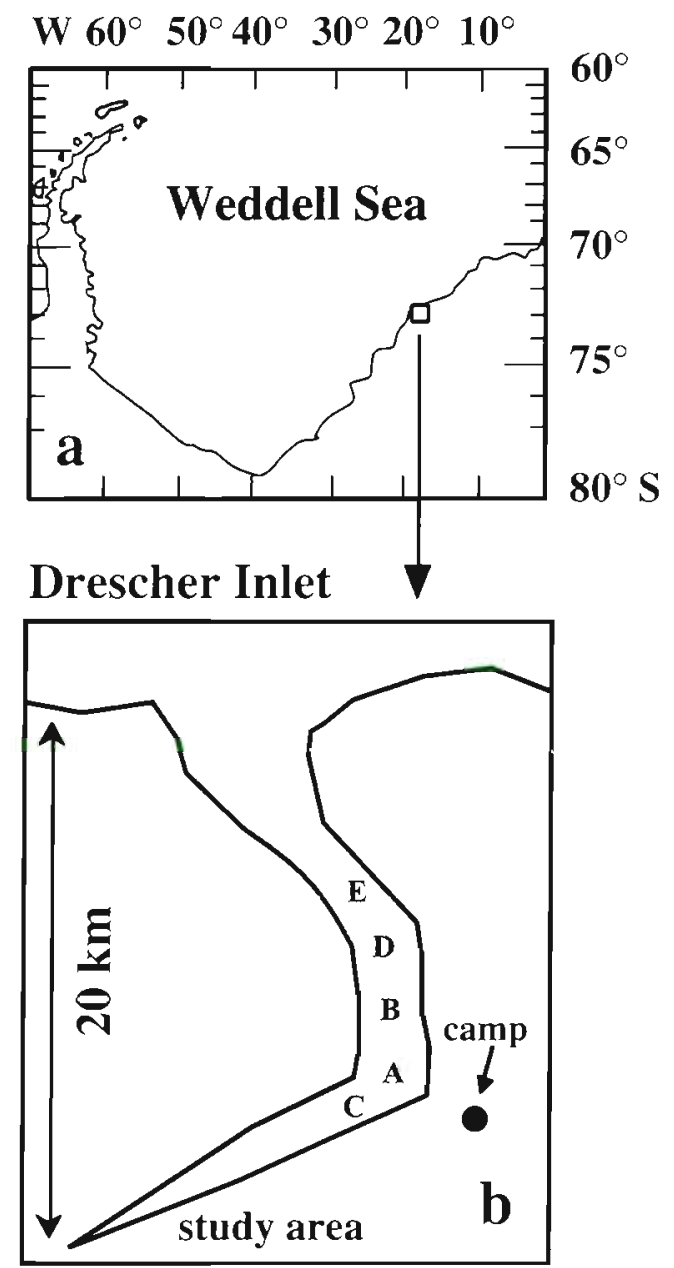

Fig. 1. (a) Location of Drescher Inlet in the eastern Weddeil Sea, (b) location of the 5 sites from which samples were collected 
study period. Samples were collected from platelet layers in the midportion of the inlet, approximately 10 to $15 \mathrm{~km}$ away from the coast. In this area, platelet ice layers with thickness ranging between 3 and $7 \mathrm{~m}$ were observed underneath the congelation ice. At several locations, platelet ice had also upwelled in small, 1 to $2 \mathrm{~m}$ wide cracks (leads) pervading the intact ice cover These cracks were often covered by a thin $(1$ to $3 \mathrm{~cm})$ layer of ice, which was either free of snow, or was covered by a dome of snow leaving a void several decimeters between the ice cover and the snow.

At 3 sites, samples were collected from platelet layers that had accumulated in cracks (Fig. 1; Sites A to C). Ice thickness of $260 \mathrm{~cm}$ and internal discolored bands of ice biota indicated the presence of secondyear sea ice. Snow depths ranged from 80 to $100 \mathrm{~cm}$. Additional samples were collected from platelet layers underlying the congelation ice (Fig. 1; Sites D to E). In this region, the sea ice was 200 to $220 \mathrm{~cm}$ thick, and was covered with 20 to $50 \mathrm{~cm}$ of snow, both typical for Weddell sea fast ice. The biomass maximum was located in the bottom $20 \mathrm{~cm}$, denoting the presence of first-year sea ice.

Sample collection. Surface samples from the interstitial water of platelet layers upwelled in cracks were collected after cautiously breaking the thin ice cover and submersing a glass bottle $5 \mathrm{~cm}$ into the platelet layer, taking care that no ice platelets became incorporated during collection. One set of bottles was filled to the rim, and stoppered without leaving an air space. These samples were stored in insulated boxes until return to the laboratory, where they were split for alkalinity and nutrient determinations approximately $1 \mathrm{~h}$ later. A second set of bottles was filled in a similar manner for oxygen determinations. A total of 11 surface samples were collected on 3 dates from randomly selected locations approximately $20 \mathrm{~m}$ apart, and 2 surface samples were collected on 2 dates from a different site at locations about $10 \mathrm{~m}$ apart.

In addition to collecting samples from the platelet layer surface, interstitial water samples were obtained from depths of 5 to $105 \mathrm{~cm}$ or 5 to $225 \mathrm{~cm}$ at $20 \mathrm{~cm}$ intervals using a modified version of the high-resolution sampler (ADONIS) described by Dieckmann et al. (1992). The apparatus consists of a plastic pipe holding 6 polyethylene tubes (i.d. $0.5 \mathrm{~cm}$ ) which are extruded after lowering the device into position in the platelet layer. Tubes are connected to a collection unit consisting of a vacuum pump applying a low vacuum of $-150 \mathrm{hPa}$ and 2 sampling bottles per tube. The first sampling bottle was filled completely by pumping water through it into the second bottle. Because the first bottle was 4 times smaller than the second one, it was sufficiently rinsed, preventing the exposure of sampled water to the atmosphere at the same time.
Subsamples for alkalinity and oxygen determinations were collected from the first bottle, nutrient subsamples were taken from the second bottle. On 2 occasions, seawater was collected from a depth of $20 \mathrm{~m}$ by lowering a 51 Niskin bottle into the sub-ice water column. At each sampling, ice platelets were scooped with a ladle and sieved through a household sieve to separate them from the interstitial water.

Physical and chemical analyses. Throughout the study area, and over the entire study period, variations of interstitial water temperature were small; the temperature ranged between -1 and $-2^{\circ} \mathrm{C}$. Salinity was measured routinely at laboratory temperature (ranging between 5 and $10^{\circ} \mathrm{C}$ ) using a microprocessor conductivity meter, calibrated prior to the study with standard seawater. On 15 February, we measured a light profile of a crack platelet layer using a Licor LI-1000 datalogger equipped with a submersible $4 \pi$ SA192 sensor and a $2 \pi$ SZ190 insolation sensor.

Oxygen concentrations were determined according to the Winkler method (Grasshoff 1983). A volumecalibrated glass reagent bottle (ca $50 \mathrm{ml}$ ) was filled either by immersing directly into the surface platelet layer or by carefully decanting water from the first ADONIS collection bottle. Winkler reagents were added, the bottle was stoppered, vigorously shaken, and transferred to the camp laboratory. For determination of in situ primary production we took 2 additional initial bottles and deployed 2 light bottles and a single dark bottle for $24 \mathrm{~h}$ at $10 \mathrm{~cm}$ depth. All 5 bottles were analyzed for oxygen concentrations as described above.

Comparison of dissolved oxygen concentrations of interstitial water obtained with the ADONIS and from samples rinsed directly into Winkler bottles (Fig. 2) clearly reveals that our modified sampling unit is well suited for profiling dissolved gases in aquatic systems. The slight underestimation of oxygen at extraordinary high concentrations may arise from the fact that gradients there were very steep and sampling depth differed slightly ( 5 to $10 \mathrm{~cm}$ with the ADONIS compared to $0 \mathrm{~cm}$ with the 'production' bottles).

After taking the oxygen sample, a second glass bottle was filled to the rim, and stoppered without leaving an air space. Upon return to the camp, the sample was allowed to warm to laboratory temperature. Subsequently, the $\mathrm{pH}$ of the sample was measured using a combination electrode connected to a microprocessor $\mathrm{pH}$ meter, calibrated daily before determinations commenced with NBS standard buffers, and allowing $>1 \mathrm{~h}$ to adjust to low ionic strength. Prior to each measurement series, the electrode was allowed to adjust to sample salinity for at least $1 \mathrm{~h}$ using interstitial water of known salinity. Thereafter, the electrode was immersed in the (previously stoppered) sample, and a stable $\mathrm{pH}$ reading (drift $<0.1 \mathrm{mV} 30 \mathrm{~s}^{-1}$ ) was recorded. 


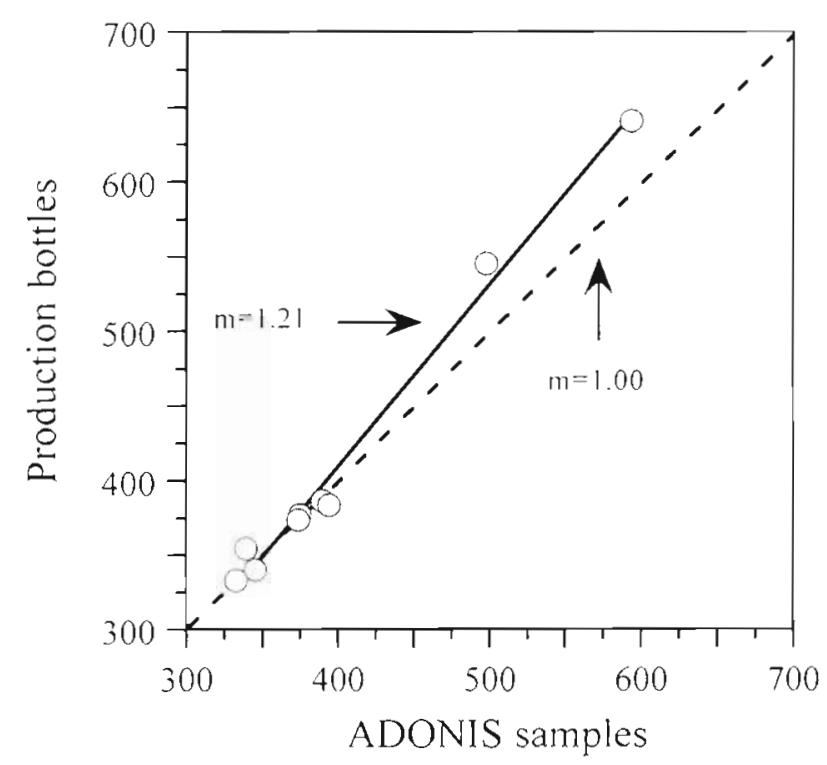

Fig. 2. Oxygen concentrations of interstitial water samples obtained with the modified ADONIS and from 'production' bottles. Solid line and slope denote results of linear regression analysis, hatched line represents $1: 1$ relationship. Unit is $\mu \mathrm{mol} \mathrm{O}_{2} \mathrm{~kg}^{-1}$ for both axes

Total alkalinity (TA) was determined using a potentiometric titration method (Almgren et al. 1983). Samples $(50 \mathrm{ml})$ were titrated with $0.05 \mathrm{~N}$ hydrochloric acid, the normality of which had been determined beforehand by iodometric titration, using an automatic burette. The second equivalence point of carbonic acid was calculated by linear regression analyses of Gran plots constructed from $25 \mathrm{pH}$ measurements in the range of $\mathrm{pH} 4$ to 3 , determined by adding $75 \mu$ increments of acid and recording $\mathrm{pH}$. The carbonate system was calculated from $\mathrm{TA}$ and $\mathrm{pH}$, using the carbonic acid dissociation constants of Mehrbach et al. (1973). Concentrations of dissolved carbon dioxide and $\mathrm{pH}$ were calculated for a temperature of $0^{\circ} \mathrm{C}$.

Nutrient subsamples $(60 \mathrm{ml})$ were filtered $(0.45 \mu \mathrm{m}$ pore size) at low vacuum, transferred to polyethylene bottles, fixed with mercuric chloride, and stored outside the laboratory in a metal box dug $50 \mathrm{~cm}$ into the meteoric ice. Temperatures inside the box varied between -8 and $-12^{\circ} \mathrm{C}$. Upon return to the ship and subsequently, nutrient samples were stored at $4^{\circ} \mathrm{C}$. Concentrations of nitrate, nitrite, phosphate and silicate were measured after 6 mo in the home laboratory using a Technicon autoanalyzer, following standard methods of Technicon modified as described in Spies et al. (1988). Storage of samples in a similar manner has been shown not to affect the inorganic nutrient concentrations (Kirkwood 1992). Each sample was analyzed twice and values averaged. Attempts to measure ammonium immediately after collection in the camp laboratory were unsuccessful due to malfunction of the spectrophotometer. Due to prolonged storage, ammonium concentrations were not determined thereafter.

Subsamples were filtered on GF/C filters for chl a determination and on precombusted GF/C filters for $\mathrm{POC}$ and PON determinations respectively. In the camp, filters were stored along with the nutrient samples. Upon return to the ship and subsequently, filters were kept frozen at $-27^{\circ} \mathrm{C}$. Chlorophyll filters were analyzed according to the method of Evans \& O'Reilly (1983). Prior to determinations, filters for POC and PON analysis were acidified with $1 \mathrm{~N}$ hydrochloric acid, and dried overnight at $60^{\circ} \mathrm{C}$. They were then transferred into tin vials, and analyzed using a CHN analyzer calibrated with acetanilide standards.

Microscopic investigations. Samples from the interstitial water were poured into brown flasks and fixed with hexamethylentetramine-buffered formalin to a final concentration of $0.5 \%$. Bottles were stored in wooden boxes inside the lab-hut. Upon return to the ship and subsequently, samples were stored along with the nutrient samples. Ice platelets were allowed to melt in GF/C filtered seawater and subsequently treated as the interstitial water samples. At the institute, samples were counted using a Zeiss ICM 405 inverted microscope after settling in 3 to $10 \mathrm{ml}$ chambers (Utermöhl 1958). Cell concentrations of bacteria were determined by epifluorescence microscopy of acridine orange-stained samples as described by Grossmann (1994).

Zooplankton were caught on 6 occasions at Sites A and B. Surface samples were scooped with a 51 plastic jar and consecutively sieved through a household sieve to separate interstitial water from ice platelets. The platelets were allowed to melt in filtered seawater and both the interstitial water and the melted platelets were concentrated using a plankton net with $30 \mu \mathrm{m}$ mesh size. Samples were preserved using the same formalin-solution as for the phytoplankton samples but to a final concentration of $5 \%$. Species identification was performed to family level for less abundant taxa and to species level and their developmental stages for the more abundant calanoid and harpacticoid copepods.

\section{RESULTS}

During February and March 1995 biomass rich algal assemblages developed in platelet layers upwelled in fast ice cracks of the Drescher Inlet. The algal community was dominated by chain-forming diatoms of the genera Fragilariopsis and Entemoneis with dinoflagellates and the prymnesiophyte Phaeocystis contributing 


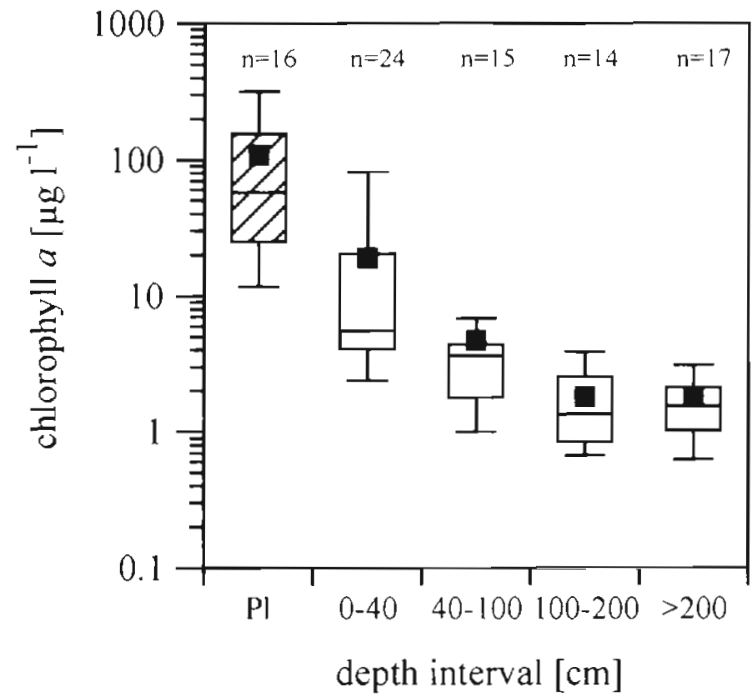

Fig. 3. Box plot of chlorophyll a concentrations of ice platelets and interstitial water samples collected from sea-ice platelet layers at Drescher Inlet during austral summer (Julian days 23 to 54). Squares denote mean concentrations, horizontal bars denote $10^{\text {th }}, 25^{\text {th }}, 50^{\text {th }}, 75^{\text {th }}$ and $90^{\text {th }}$ percentiles (from bottom to top). Pl: ice platelets

less than $30 \%$ of algal abundances on average. The proportion of empty cells were generally less than $20 \%$ in surface samples. In contrast the proportion of empty cells in under-ice samples varied between 40 and $75 \%$, this proportion ranged from 20 to $50 \%$ in samples with high phosphate concentrations. Mean chlorophyll concentrations of the interstitial water peaked at $10 \mathrm{\mu g} \mathrm{l}^{-1}$ near the surface and decreased with depth (Fig. 3). Algal standing crop attached to ice platelets exceeded that in the interstitial water by approximately 1 order of magnitude. Highest standing stocks in interstitial waters of $26.7 \mathrm{mg} \mathrm{m}^{-2}$ were found on 7 February at Site A. This amounts to a total of $150 \mathrm{mg} \mathrm{m}^{-2}$ if corrected for the contribution of attached biomass (assuming a water/ice platelet ratio of 1:1). POC concentrations of surface interstitial water vary between 43 and $800 \mu \mathrm{mol} \mathrm{Cl} \mathrm{Cl}^{-1}$. Again, this is an underestimation of the total POC as the attached proportion was not determined. Bacterial numbers ranged from $0.7 \times 10^{7}$ to $1.6 \times$

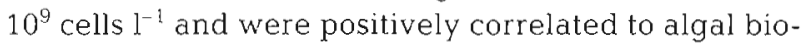
mass (Spearmann rank correlation $r_{s}=0.77 ; n=45 ; \mathrm{p}<$ 0.0001 ) with the exception of Site $C$, where bacterial numbers were in the same range despite consistently low chl a concentrations. The zooplankton consisted primarily of copepods ranging in abundance from 140 to 400 individuals $\mathrm{I}^{-1}$. Relative abundances between calanoids and harpactacoids or their developmental stages revealed no obvious trend.

A light profile was measured only once on 15 February at Site B where the crack was shielded by a bridge of snow with a thickness of $10 \mathrm{~cm}$, ca $70 \mathrm{~cm}$ above the sea-surface. Incident light levels at $5 \mathrm{~cm}$ depth were $8 \%\left(107 \mathrm{HE} \mathrm{m}^{-2} \mathrm{~s}^{-1}\right)$ of the surface insolation and decreased exponentially to $0.1 \%$ at $1 \mathrm{~m}$ depth corresponding to $1 \mu \mathrm{E} \mathrm{m}^{-2} \mathrm{~s}^{-1}$ at that date. Two time series were recorded: first between 1 February and 6 February, under $2 \mathrm{~m}$ of fast ice covered by $1 \mathrm{~m}$ of snow (Site D) where PAR never exceeded values of $0.25 \mu \mathrm{E} \mathrm{m}^{-2} \mathrm{~s}^{-1}$, and second from 15 February to 19 February at Site B. Noon light levels there ranged between 30 and $34 \mu \mathrm{E} \mathrm{m}^{-2} \mathrm{~s}^{-1}$ at a depth of $30 \mathrm{~cm}$.

Salinity varied between 25.8 and 33.5 (Table 1), indicating the influence of meltwater on concentrations of dissolved constituents in many samples. This was corrected for by normalizing all data to a salinity of 35 . We do not expect air/sea exchange of gaseous constituents to have significantly influenced the composition of samples collected from cracks, because the upper platelet layer was shielded from direct contact with the atmosphere by a thin cover of solid ice that had to be broken prior to sample collection.

The salinity-normalized, average composition of the sub-ice seawater at $20 \mathrm{~m}$ depth (2 samples collected on Julian days 52 and 53) was $2158 \mu \mathrm{mol}$ DIC kg-1, $375 \mu \mathrm{mol} \mathrm{O} \mathrm{kg}^{-1}, 21.3 \mu \mathrm{mol} \mathrm{NO}_{3} \mathrm{~kg}^{-1}, 48.1 \mu \mathrm{mol}$ $\mathrm{Si}(\mathrm{OH})_{4} \mathrm{~kg}^{-1}$, and $1.54 \mu \mathrm{mol} \mathrm{PO}_{4} \mathrm{~kg}^{-1}$. These concentrations coincided with those prevalent in platelet layers below a depth of $1 \mathrm{~m}$. In contrast, silicate and especially nitrate were exhausted in many surface samples whereas phosphate attained extraordinary high accumulations of up to $15.3 \mu \mathrm{mol} \mathrm{kg} \mathrm{kg}^{-1}$ (Fig. 4).

Salinity-normalized dissolved inorganic carbon concentrations of interstitial water samples ranged from 1545 to $2184 \mu \mathrm{mol} \mathrm{kg}{ }^{-1}$. This is reflected by the normalized dissolved oxygen concentrations ranging

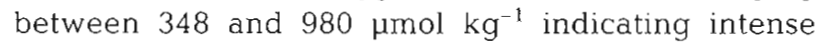
photosynthetic carbon fixation (Table 1). Thus, carbon uptake at Redfield ratio would only account for a DIC depletion of $145 \mu \mathrm{mol} \mathrm{kg}{ }^{-1}$ (at present nitrate con-

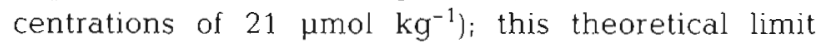
predicted from complete nutrient consumption was exceeded in most interstitial surface water samples (Fig. 5) and considerable DIC depletion up to $100 \mu \mathrm{mol}$ $\mathrm{kg}^{-1}$ was also recorded down to $1 \mathrm{~m}$ depth. Nevertheless, DIC depletion was almost always lower than interstitial POC concentrations; this result was even more pronounced if the attached proportion of POC was also taken into account.

\section{DISCUSSION}

Although platelet layers occur at many locations around the Antarctic underneath land-fast ice or under drifting pack ice (Ackley \& Sullivan 1994), their pro- 
Table 1. Excerpt of data of biotic and abiotic parameters measured on platelet layers in Drescher Inlet, 1995. Data are not corrected for salinity. Note different depth scale for Site E. ns: not sampled

\begin{tabular}{|c|c|c|c|c|c|c|}
\hline $\begin{array}{c}\text { Depth } \\
(\mathrm{cm})\end{array}$ & $\begin{array}{l}\text { Site B } \\
07 \text { Feb }\end{array}$ & $\begin{array}{l}\text { Site B } \\
15 \text { Feb }\end{array}$ & $\begin{array}{l}\text { Site B } \\
23 \text { Feb }\end{array}$ & $\begin{array}{c}\text { Site C } \\
09 \text { Feb }\end{array}$ & $\begin{array}{l}\text { Depth } \\
\text { (cm) }\end{array}$ & $\begin{array}{l}\text { Site E } \\
22 \mathrm{Feb}\end{array}$ \\
\hline \multicolumn{7}{|c|}{ Chlorophyll a ( $\mu \mathrm{g} \mathrm{l}^{-1}$ ) } \\
\hline 10 & 88.91 & 28.78 & 10.61 & 2.56 & 210 & 2.22 \\
\hline 30 & 31.06 & 29.42 & 4.92 & 4.27 & 230 & 1.07 \\
\hline 50 & 6.55 & 25.29 & 3.92 & 3.63 & 250 & 1.71 \\
\hline 70 & 4.13 & 6.84 & 2.42 & 2.07 & 270 & 0.63 \\
\hline 90 & 1.71 & 4.49 & 3.99 & 1.35 & 290 & 0.91 \\
\hline 110 & 1.28 & 3.78 & 2.56 & 2.14 & 310 & 1.37 \\
\hline \multicolumn{7}{|c|}{ Nitrate $\left.(\mu \mathrm{mol} \mathrm{l})^{-1}\right)$} \\
\hline 10 & 5.54 & 20.40 & 22.99 & 0.47 & 210 & 20.92 \\
\hline 30 & 19.98 & 21.16 & 22.60 & 5.65 & 230 & 20.36 \\
\hline 50 & 20.35 & 20.88 & 22.32 & 13.30 & 250 & 20.42 \\
\hline 70 & 20.32 & 21.55 & 22.61 & 15.59 & 270 & 20.90 \\
\hline 90 & 21.04 & 21.63 & 22.87 & 15.58 & 290 & 20.89 \\
\hline 110 & 20.63 & 21.90 & 21.56 & 15.47 & 310 & 20.58 \\
\hline \multicolumn{7}{|c|}{ Silicate $\left(\mu \mathrm{mol} \mathrm{l}{ }^{-1}\right)$} \\
\hline 10 & 18.59 & 43.81 & 48.31 & 17.65 & 210 & 45.05 \\
\hline 30 & 43.56 & 46.91 & 47.84 & 22.30 & 230 & 43.93 \\
\hline 50 & 44.59 & 48.49 & 47.29 & 34.12 & 250 & 44.69 \\
\hline 70 & 45.43 & 47.64 & 48.01 & 37.12 & 270 & 45.01 \\
\hline 90 & 45.69 & 47.40 & 48.87 & 37.38 & 290 & 44.53 \\
\hline 110 & 44.73 & 47.61 & 45.72 & 36.49 & 310 & 44.37 \\
\hline \multicolumn{7}{|c|}{ Phosphate ( $\mu \mathrm{mol} \mathrm{l^{-1 } )}$} \\
\hline 10 & 0.89 & 2.13 & 2.28 & 11.60 & 210 & 1.47 \\
\hline 30 & 1.54 & 2.21 & 2.24 & 12.12 & 230 & 1.44 \\
\hline 50 & 1.52 & 2.17 & 2.19 & 5.44 & 250 & 1.44 \\
\hline 70 & 1.73 & 2.28 & 2.24 & 3.66 & 270 & 1.47 \\
\hline 90 & 1.72 & 2.20 & 2.30 & 2.68 & 290 & 1.46 \\
\hline 110 & 1.71 & 2.24 & 2.13 & 2.06 & 310 & 1.46 \\
\hline \multicolumn{7}{|c|}{ Salinity (psu) } \\
\hline 10 & 33.0 & 33.3 & 33.1 & 25.8 & 210 & 33.4 \\
\hline 30 & 33.4 & 33.3 & 33.3 & 27.9 & 230 & 33.4 \\
\hline 50 & 33.4 & 33.3 & 33.4 & 31.4 & 250 & 33.5 \\
\hline 70 & 33.4 & 33.3 & 33.5 & 32.7 & 270 & 33.5 \\
\hline 90 & 33.4 & 33.4 & 33.5 & 32.7 & 290 & 33.5 \\
\hline 110 & 33.4 & 33.5 & 33.5 & 32.8 & 310 & 33.5 \\
\hline \multicolumn{7}{|c|}{ Oxygen $\left(\mu \mathrm{mol} \mathrm{l}^{-1}\right)$} \\
\hline 10 & 498 & 394 & 348 & 743 & 21.0 & 376 \\
\hline 30 & 387 & 367 & ns & 641 & 230 & 371 \\
\hline 50 & 373 & 368 & 343 & 496 & 250 & 374 \\
\hline 70 & 364 & 370 & 353 & 445 & 270 & 375 \\
\hline 90 & 358 & 365 & ns & 438 & 290 & 380 \\
\hline 110 & 360 & 356 & 352 & 435 & 310 & 374 \\
\hline \multicolumn{7}{|c|}{$\operatorname{POC}\left(\mu \mathrm{mol} \mathrm{l}^{-1}\right)$} \\
\hline 10 & 609.9 & 242.3 & 59.5 & 59.2 & 210 & 23.0 \\
\hline 30 & 174.1 & 151.2 & 56.8 & 67.2 & 230 & 44.5 \\
\hline 50 & 39.7 & 117.4 & 27.4 & 49.6 & 250 & 10.9 \\
\hline 70 & 36.1 & 39.7 & 22.4 & 55.3 & 270 & 13.1 \\
\hline 90 & 13.2 & 32.3 & 39.5 & 57.2 & 290 & 10.7 \\
\hline 110 & 7.2 & 28.1 & 22.6 & 43.2 & 310 & 14.0 \\
\hline \multicolumn{7}{|c|}{ PON $\left(\mu \mathrm{mol} \mathrm{l}^{-1}\right)$} \\
\hline 10 & 89.7 & 35.3 & 7.5 & 7.2 & 210 & 2.5 \\
\hline 30 & 26.4 & 22.2 & 9.0 & 9.3 & 230 & 3.5 \\
\hline 50 & 5.8 & 17.5 & 3.7 & 7.9 & 250 & 1.2 \\
\hline 70 & 6.6 & 6.4 & 3.3 & 9.7 & 270 & 1.5 \\
\hline 90 & 4.0 & 5.0 & 5.7 & 9.8 & 290 & 1.2 \\
\hline 110 & 1.9 & 4.4 & 2.8 & 7.2 & 310 & 1.7 \\
\hline
\end{tabular}
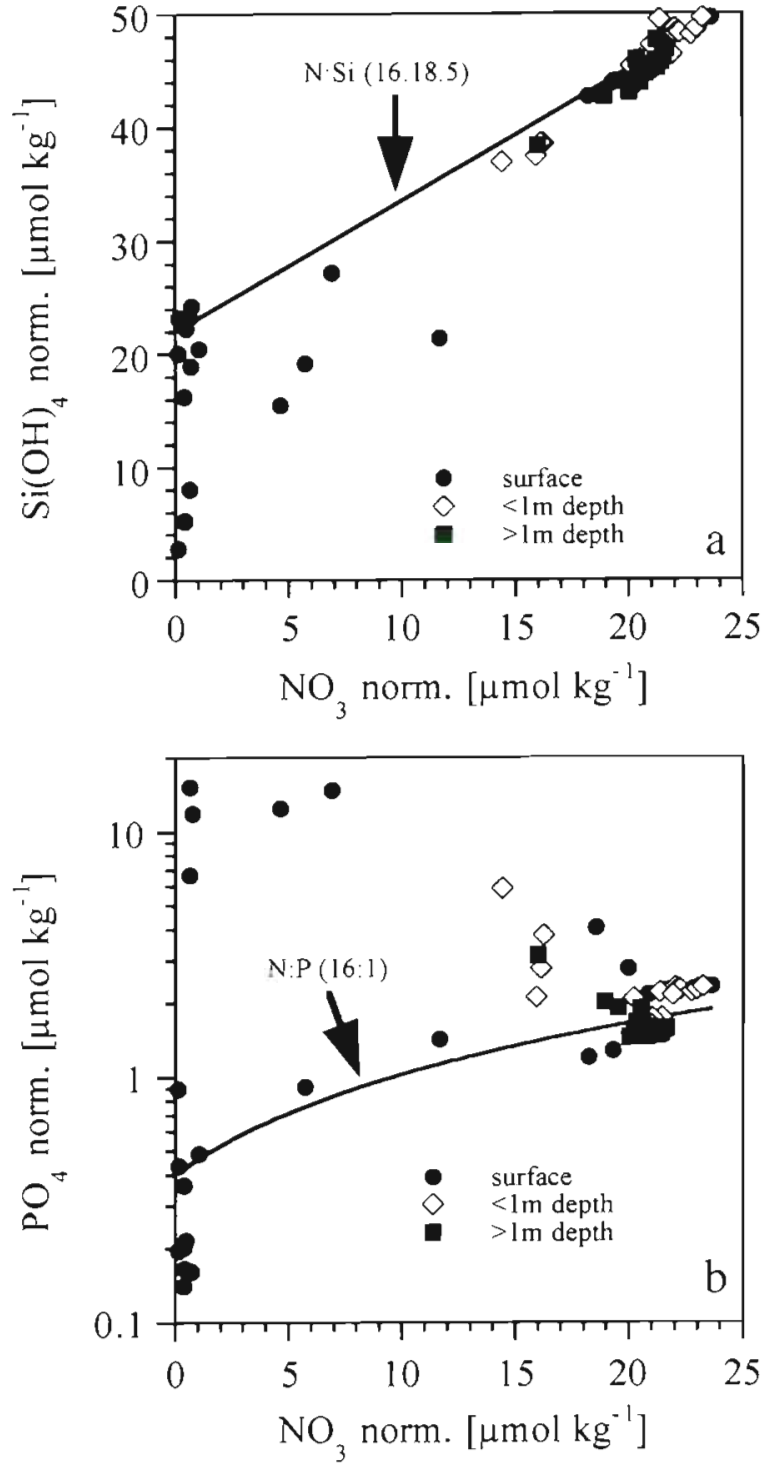

Fig. 4. Salinity-normalized (a) silicate $\left(\mathrm{Si}[\mathrm{OH})_{4}\right)$, and (b) phosphate $\left(\mathrm{PO}_{4}\right)$ vs nitrate $\left(\mathrm{NO}_{3}\right)$ concentrations of interstitial water samples collected from sea-ice platelet layers at Drescher Inlet during austral summer (Julian Days 23 to 54). Solid line in a denotes N:Si ratio for sea-ice diatoms (Arrigo et al. 1995), solid line in b denotes N:P ratio of $16: 1$. Note logarithmic scale in $b$

portion of the total sea-ice extent is relatively low. Furthermore the majority of samples collected for this study originated from platelet layers that had upwelled in cracks in the fast ice of the Drescher Inlet. Yet we consider the conditions we found to occur in a variety of semi-enclosed sea-ice habitats commonly found in Antarctica

Platelet layers occurring in cracks are isolated laterally by the sea ice and from below by the ice platelets themselves. Therefore, seawater exchange is consider- 


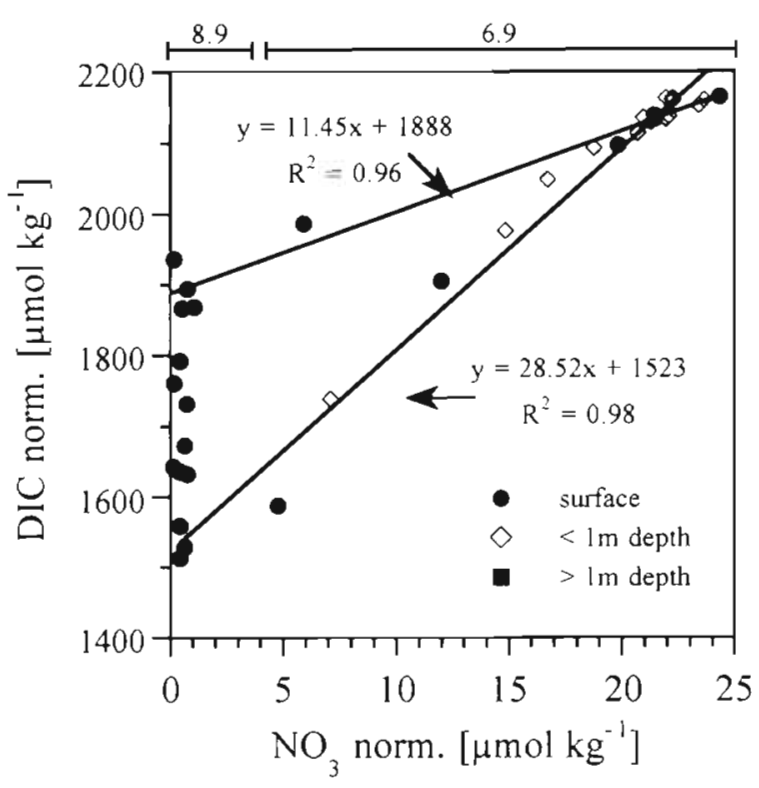

Fig. 5. Salinity-normalized dissolved inorganic carbon (DIC), vs nitrate $\left(\mathrm{NO}_{3}\right)$ concentrations of interstitial water samples collected from sea-ice platelet layers at Drescher Inlet during austral summer (Julian days 23 to 54). Solid lines and equations denote results of linear regression analyses of the 2 extreme trends in DIC to nitrate uptake ratios. Numbers above the graph denote mean POC:PON ratios of samples within the range of the bars; $\mathrm{SD}$ is 1.3 for $\mathrm{C} / \mathrm{N}=6.9$ and 2.2 for $\mathrm{C} / \mathrm{N}=8.9$

ably restricted, as it is in melt pools (Gleitz et al. 1996a), free board layers within ice floes (Fritsen et al 1994), internal layers of rotten ice (Thomas et al. 1998), pack ice platelet layers (Smetacek et al. 1992), and the bottom zone in sea ice immediately above the ice/ water interface (Smith et al. 1989). We discuss here nutrient and DIC dynamics in crack platelet layers and develop a conceptual model representative for semienclosed sea-ice ecosystems where nutrients and not light limit algal growth.

\section{Biological and geochemical boundary conditions}

Biomass data imply that considerable algal growth within platelet layers at Drescher Inlet occurred primarily in cracks in the fast ice where platelets rose to the surface. This is supported by in situ light measurements that revealed light levels beneath snow covered fast ice to be below the photosynthetic compensation point for sea-ice algae (Bunt 1964, Cota 1985). As in platelet layers elsewhere (Dieckmann et al. 1992), algal biomass is not only freely suspended within the interstitial water but a large proportion is also attached to the ice platelets. Therefore, the majority of algae are confined within the habitat. In accord with other stud-

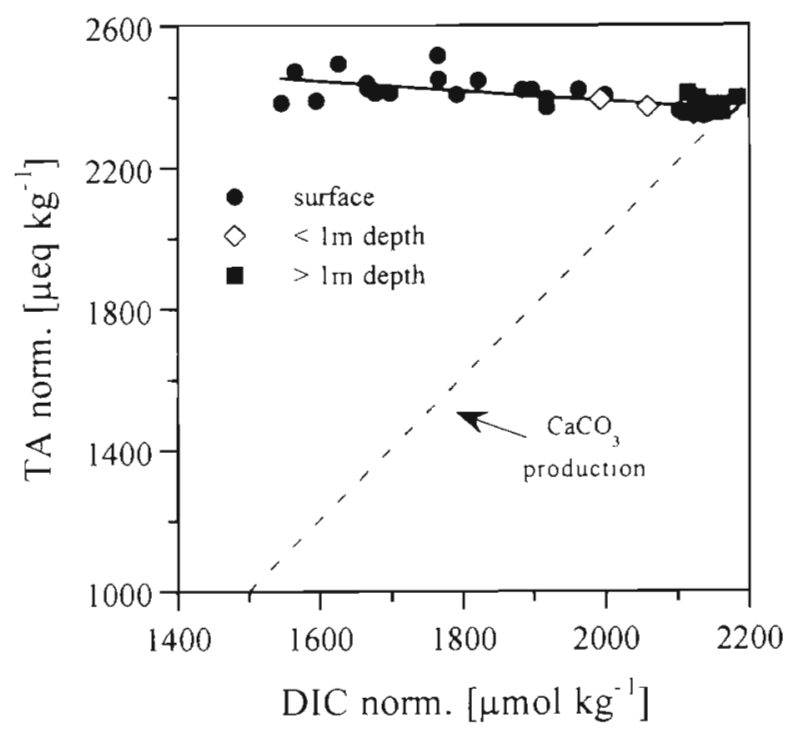

Fig. 6. Salinity-normalized total alkalinity (TA) vs dissolved inorganic carbon (DIC) concentrations of interstitial water samples collected from sea-ice platelet layers at Drescher Inlet during austral summer (Julian days 23 to 54 ). Solid line and equation denote results of linear regression analysis, hatched line denotes the TA vs DIC relationship expected from calcium carbonate production

ies on taxonomic composition of platelet layers in the southern Weddell Sea (Smetacek et al. 1992, Grossmann et al. 1996), the algal biomass at Drescher Inlet consists predominantly of diatoms.

Salinity-normalized concentrations of dissolved inorganic carbon and dissolved oxygen of surface interstitial water reflect various stages of productivity within crack platelet layers. Concentrations of these gases may be influenced by advection of sub-ice water into platelet layers in addition to local production and respiration. Atmospheric exchange was probably negliglble because all cracks were shielded from direct contact with the atmosphere by a thin layer of solid ice that had to be broken prior to sample collection. Furthermore, precipitation of calcium carbonate could be excluded, as it is associated with a reduction of total alkalinity (TA); for each mol of calcium carbonate formed, $1 \mathrm{~mol}$ of DIC and 2 equivalents of alkalinity are removed from the water. In the samples analyzed here, TA actually increased slightly with decreasing DIC concentrations (Fig. $6 ; p=0.018$ ), as would be expected when nitrate is taken up by primary production (Brewer \& Goldman 1976). However, the photosynthetic quotient $(P Q)$ revealed ammonium to be an additional nitrogen source. Laws (1991) showed that PQ normally ranges between 1.1 and 1.4 depending on the redox state of the nitrogen source where lower values indicate uptake of ammonium. Our data reveal a PQ of 0.9 (Fig. 7), but when corrected by the result of the 


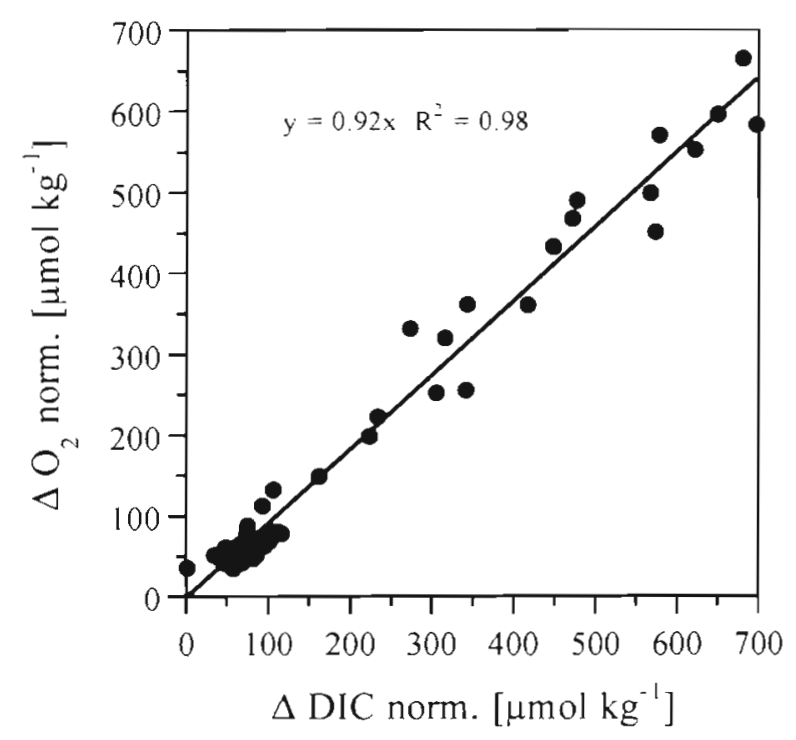

Fig. 7 Salinity-normalized molecular oxygen $\left(\mathrm{O}_{2}\right)$ vs dissolved inorganic carbon (DIC) concentrations of interstitial water samples collected from sea-ice platelet layers at Drescher Inlet during austral summer (Julian days 23 to 54). Solid line and equation represent results of linear regression analysis

regression in Fig. 2, PQ increases to 1.1, substantiating the uptake of ammonium.

Nutrient concentrations of the water column are lower than typical winter mixed layer values in the southeastern Weddell Sea (Scharek et al. 1994), indicating that the composition of the sub-ice seawater was affected by primary production that had presumably taken place in surface waters of the ice-free coastal current prior to advection beneath the sea ice of Drescher Inlet. Furthermore, water column nutrient concentrations equal those of platelet layers underneath fast ice, showing that nutrient uptake there is lower than the rate of replenishment. This is in accord with investigations of platelet layers under fast ice in McMurdo Sound where nutrients are replete even at algal standing stocks of $1 \mathrm{~g} \mathrm{chl} \mathrm{a} \mathrm{I}^{-1}$ (Arrigo et al. 1995). The same is true for nutrient concentrations of interstitial crack water were algal biomass is low. However, during maturation of the bloom the biogeochemical situation in crack platelet layers differs significantly from those platelet layers in which mixing takes place as is discussed below

\section{Biogeochemical conditions in crack platelet layers}

As the exchange of seawater is substantially restricted, nutrient uptake by algae in crack platelet layers surpasses rates of replenishment. In many surface samples nitrate is completely exhausted or at least below the half-saturation constant for Antarctic fast ice algae (Priscu \& Sullivan 1998). Smetacek et al. (1992) found the same situation in platelet layers under drifting pack ice that is not affected by tidal currents. Assuming a nutrient replete biochemical composition of C:N:Si:P = 107:16:18.5:1 for ice diatoms (Arrigo et al. 1995), and comparing this with ratios of winter mixed layer nutrients (C:N:Si:P = 1100:15:38.5:1), we expect nitrate depletion to occur first, taking into account that experiments with natural Antarctic algal assemblages (Nelson \& Tréguer 1992) revealed much higher silicate uptake affinities than found in laboratory experiments (Jacques 1983, Arrigo et al, 1993b). Furthermore, nitrate and silicate are removed from the water at a ratio of 16:18.5 (Arrigo et al. 1995) as long as nitrate is sufficient and even then silicate concentrations still decrease (Fig. 3a) which indicates further algal growth. But as nitrate is essential for cell division, nitrogen has to be resupplied in some form to support continuing silicate removal. At the same time phosphate often surpasses winter seawater concentrations by an order of magnitude or at least exceeds that predicted from nitrate consumption at a Redfield ratio of 16:1 (phosphate should decrease from $1.5 \mu \mathrm{mol} \mathrm{kg-1}$ to $0.2 \mu \mathrm{mol} \mathrm{kg} \mathrm{kg}^{-1}$ if nitrate decreases from $22 \mu \mathrm{mol} \mathrm{kg} \mathrm{kg}^{-1}$ to $1 \mu \mathrm{mol} \mathrm{kg} \mathrm{kg}^{-1}$ ). Salinity-corrected phosphate concentrations surpassing seawater values were also measured in samples collected from platelet layers beneath fast ice (Dieckmann et al. 1992, Arrigo et al. 1995), as well as pack ice (Garrison et al. 1990, Dieckmann et al. 1991), pointing to efficient in situ regeneration and accumulation of regenerated nutrients. A conceptual model is shown below, explaining these unusual nutrient concentrations.

While phosphate is at extraordinarily high concentrations the contrary is the case for dissolved inorganic carbon. If carbon and nitrogen were taken up at Redfield ratios (Redfield 1958), nitrate concentrations of the water column would allow DIC uptake of $146 \mu \mathrm{mol}$ $\mathrm{kg}^{-1}$ resulting in concentrations of $2012 \mu \mathrm{mol} \mathrm{DIC} \mathrm{kg}{ }^{-1}$ which does not explain the DIC concentrations of down to $1500 \mu \mathrm{mol} \mathrm{kg}{ }^{-1}$ that are observed here. Banse (1994) re-evaluated 2 experiments performed by McAllister et al. (1961) and Antia et al. (1963) regarding the uptake of DIC and nitrate and found that carbon uptake was uncoupled from nitrate uptake as DIC was removed at a constant rate even when nitrate consumption had ceased. However, DIC depletion by up to several hun-

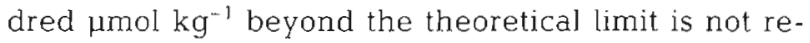
stricted to crack platelet layers. For example, Gleitz et al. (1995) analyzed the chemical composition of brine collected from pack ice in the Southern Weddell Sea during the summer, and later analyzed water collected from pools of meltwater trapped between ice floes in the same investigation area (Gleitz et al. 1996a). In both 
studies, the authors found the same elevated phosphate concentrations as well as extraordinarily high DIC depletion. Therefore, data presented here reflect stages in the developmental history of ice algal blooms representative for other sea-ice habitats.

Based on ours and other data we provide a conceptual model of biogeochemical processes in semienclosed sea-ice ecosystems. Major parameters in this concept are the physical boundary conditions, which determine the rate of exchange between the ice ecosystem and the surrounding seawater, and the physiological capacity of the ice biota to remain metabolically active despite shifts in environmental conditions. We propose a temporal succession characterized by a phase dominated by algal utilization of nutrients advected into the system (phase of nitrate-based, 'new' production), followed by a phase during which primary production relies on liberated internal nutrient pools and algal metabolism is directed towards production and accumulation of carbon-rich metabolites. This model is elaborated in the following sections.

\section{Phase I (nitrate-based production)}

During the early stages of sea-ice algal blooms, sustained replenishment of nutrients from the surrounding water column through convection or turbulent diffusion will lead to rapid accumulation of organically bound carbon, nitrogen, and phosphorus as well as biogenic silica in excess of what is accounted for by instantaneous DIC and nutrient deficiencies. In our study, this is documented by concentrations of POC exceeding the DIC depletion in many samples collected at Site B (Table 2). Our data also show that during mat. uration of the bloom, the nutrient demand of the accumulating algal biomass exceeds replenishment, leading to variations of $\mathrm{DIC}, \mathrm{O}_{2}$ and the 'new' nutrients advected into the system. Apparently, nitrate-based production proceeds in general accord with Redfield stoichiometries, which is indicated by the close correlation between silicate versus nitrate depletion (Fig. 4a) and POC/PON ratio (Fig 5), as long as 'new' nutrients (represented by nitrate) are present in nonlimiting quantities. The phosphate versus nitrate relationship observed here (Fig. 4 b) also suggests that nutrient regeneration during this phase can already be substantial, leading to accumulation of regenerated nutrients. In accord with our data, pronounced accumulation of regenerated nutrients was observed in platelet layers underlying fast ice at McMurdo Sound, despite frequent exchange with the sub-ice seawater (Arrigo et al. 1995). However, DIC versus nitrate relationship already points to non-Redfield uptake metabolism even at nutrient replete state (Fig. 5).
Table 2. Concentrations of particulate organic carbon (POC) and dissolved inorganic carbon (DIC) at Drescher Inlet (Site B). POC attached to ice platelets not included. $\triangle D I C$ was calculated by subtracting each concentration from water column value

\begin{tabular}{|lrccc|}
\hline $\begin{array}{l}\text { Julian } \\
\text { day }\end{array}$ & $\begin{array}{c}\text { Depth } \\
(\mathrm{cm})\end{array}$ & $\begin{array}{c}\text { POC } \\
\left.(\mu \mathrm{mol} \mathrm{l})^{-1}\right)\end{array}$ & $\begin{array}{c}\text { DIC } \\
\left(\mu \mathrm{mol} \mathrm{l}^{-1}\right)\end{array}$ & $\begin{array}{c}\Delta \mathrm{DIC} \\
\left(\mu \mathrm{mol}^{-1}\right)\end{array}$ \\
\hline 30 & 5 & 747 & 1795 & 342 \\
37 & 5 & 676 & 1830 & 307 \\
38 & 5 & 534 & 1926 & 211 \\
38 & 25 & 165 & 2096 & 41 \\
38 & 45 & 67 & 2099 & 38 \\
38 & 65 & 51 & 2089 & 48 \\
38 & 85 & 45 & 2098 & 39 \\
38 & 105 & 22 & 2135 & 2 \\
46 & 5 & 242 & 2088 & 49 \\
46 & 25 & 151 & 2113 & 24 \\
46 & 45 & 117 & 2116 & 21 \\
46 & 105 & 28 & 2110 & 27 \\
54 & 5 & 60 & 2105 & 32 \\
54 & 45 & 27 & 2112 & 25 \\
54 & 65 & 22 & 2127 & 10 \\
52 & 2000 & 17 & 2137 & water column \\
& & & & \\
\hline
\end{tabular}

If exchange with the surrounding seawater is sufficient to always maintain nutrients at non-limiting concentrations, the phase of 'new' production can be sustained until self-shading due to the dense concentration of algal pigments will terminate the bloom. This situation has been documented for platelet layers underlying fast ice at McMurdo Sound (Arrigo et al. 1993b, 1995). At Drescher Inlet, the special crack situation and a thicker platelet layer was apparently responsible for lower rates of nutrient fluxes from the sub-ice seawater, and consequently, lower rates of algal biomass accumulation. Accordingly, 'new' nutrients can be fully consumed before light levels become limiting

\section{Phase II (production directed towards carbon-rich metabolites)}

The pronounced DIC overconsumption relative to nitrate (Fig. 5) indicates that ice algal carbon fixation continues even after nitrate is exhausted. Previous studies have shown that one mechanism by which this can be achieved is alteration of cellular biochemistry during phases of nitrate deprivation. In a laboratory study using a clone of Thalassiosira antarctica isolated from the Southern Ocean, Peters \& Thomas (1996a) observed resting cell formation, decline (but not cessation) of photosynthetic activity, and production of nitrogen-poor metabolites during a 21 d nitrate exhaustion experiment, resulting in $\mathrm{C} / \mathrm{N}$ ratios of the algal organic matter as high as 34 . Similar observations were also 
reported from natural ice algal assemblages collected in the field. Gleitz et al. (1996a) measured C/N ratios of up to 15 in the (diatom-dominated) samples collected from the pools of meltwater referred to above, which was associated with massive lipid accumulation within algal cells (Fahl \& Kattner 1993). Similarly, C/N ratios of up to 25 were recorded by Priscu \& Sullivan (1998) in samples collected from fast ice at McMurdo Sound, Ross Sea. An 'overflow production' of carbon-rich reserve material of the same magnitude as observed by Peters \& Thomas (1996a) would in fact be sufficient to explain the surplus DIC depletion observed in the present study. $\mathrm{C} / \mathrm{N}$ ratios of particulate matter varied between 4.5 and 12.8, and often exceeded the 'balanced' ratio of 6.6 even at high nitrate concentrations (Fig. 5). A maximum $\mathrm{C} / \mathrm{N}$ ratio of 13 as measured here would only account for a DIC overconsumption of roughly $200 \mathrm{mmol} \mathrm{kg}^{-1}$, and would thus explain only part of the observed depletion of up to $450 \mu \mathrm{mol}$ DIC $\mathrm{kg}^{-1}$ recorded at Site A (Fig. 5). Although it is known that phytoplankton release organic compounds extracellularly (Larsson \& Hagström 1982, Lignell 1990), there are not enough data sets of in situ DOM concentrations to sufficiently explain the fate of the excessive carbon fixation. Arrigo et al. (1995) detected simple sugars and amino acids in platelet layers in much higher concentrations than in the underlying water column. Within internal sea-ice slush layers, Thomas et al. (1998) measured DOC concentrations up to $600 \mu \mathrm{mol} \mathrm{l^{-1 }}$ strongly correlated with chl a. Furthermore, in Arctic sea ice Thomas et al. (1995) found DOC to be uncoupled from DON concentrations but there DOC was not correlated with chl a. From this we surmise a shift of fixed carbon from cell growth to dissolved organic matter (DOM) with a high $\mathrm{C} / \mathrm{N}$ ratio at nutrient deplete state.

This is notable also because current estimates of total ice-related carbon production (Legendre et al. 1992, Arrigo et al. 1997) do not take dissolved organic matter into account. Thus, the study of Thomas et al. (1998) and the data presented here strongly suggest that consideration of DOM production by sea-ice microalgae is likely to result in a significantly higher total production estimate.

In the remainder of the discussion, we will focus on possible pathways by which nutrients may have been regenerated.

\section{Pathways of nutrient recycling within sea-ice ecosystems}

Previous accounts of nutrient dynamics in sea-ice habitats have frequently invoked heterotrophic remineralization as a foremost explanation for elevated phosphate or ammonium concentrations (Garrison et al. 1990, Dieckmann et al. 1991, 1992, Arrigo et al. 1995). The main heterotrophic consumers in sea-ice ecosystems are bacteria and phagotrophic flagellates (Garrison 1991). A specialized crustacean fauna, in particular small copepods, has also been observed within the solid sea ice and at the ice/seawater interface, where they feed on ice algae (Dahms et al. 1990, Conover \& Huntley 1991, Kurbjeweit et al. 1993, Schnack-Schiel et al. 1995, Tanimura et al. 1996). However, previous studies have failed to detect metazoan grazers in platelet layers in any significant numbers (Dieckmann et al. 1992. Smetacek et al. 1992, Grossmann et al. 1996). In the light of these reports, a most remarkable finding of this study is the presence of large stocks of metazooplankton in platelet layers at Drescher Inlet. In contrast, numbers of heterotrophic protozoans were negligible so bacteria and copepods were the main consumers of algal primary production here.

It is well established that feeding copepods release inorganic phosphorus and ammonium, as well as dissolved organic matter into the surrounding water (Butler et al. 1969, Ikeda \& Mitchell 1982, Le Borgne 1986). It must be emphasized, however, that over longer (seasonal) time scales, heterotrophic production of ammonium and phosphate, would consume oxygen (while releasing carbon dioxide) in about the same proportions in which it was removed from the water during primary production, as, with the exception of silicon, the biochemical composition of the heterotrophs does not differ fundamentally from that of the phytoplankton (Conover \& Huntley 1991, Fagerbakke et al. 1996). In our study, however, phosphate accumulation was associated with substantial DIC depletion (Fig. 3b) and strong oxygen oversaturation. Based on this data, we suspect that heterotrophic oxidation of algal organic matter and excretion of metabolic endproducts may not represent a major pathway by which nutrients are regenerated in similar sea-ice ecosystems. In contrast to previous speculation, we suggest that liberation of dissolved matter including nutrients from the large biomass pool that had accumulated during a phase when nutrient replenishment exceeded algal uptake must have been a major process by which nutrients were released into interstitial waters without proportional oxygen consumption or carbon dioxide release. Subsequently, we will refer to this way of nutrient release as 'liberation', opposed to 'regeneration', which implies assimilation and excretion of metabolic end products. Such nutrient liberation may partly be related to algal mortality and cell lysis, and may also be amplified by inefficient ('sloppy') feeding when metazoan grazers are present

In the presence of large prey sizes (e.g. large cells or algal chains) and high food concentrations, copepods 
have been shown to feed inefficiently, resulting in algal cell fragmentation and ingestion of only a fraction of the cellular debris produced (O'Connors et al. 1976 , Roy et al. 1989). In samples considered here, the dominant diatoms growing attached to ice platelets as well as suspended in the interstitial waters were chainforming species belonging to the genera Fragilariopsis and Entemoneis, which are likely to be disrupted during copepod feeding. Mechanical disruption of food particles will lead to liberation of particulate and dissolved organic matter as well as fragmentation of silica frustules. The higher proportion of empty cells in samples where phosphate concentrations were also elevated gives an indication that this process occurred here. In diatom-dominated samples collected from various sea-ice habitats at McMurdo Sound, Priscu \& Sullivan (1998) measured millimolar intracellular concentrations of nitrate, ammonium and soluble reactive phosphorus, indicating that ice algae contain substantial internal inorganic nutrient pools, possibly related to high-affinity uptake systems but less efficient assimilation into metabolites. These nutrients would be liberated and made available to the phytoplankton upon cell disruption and lysis. Clearly, liberation of phosphorus (and presumably ammonium) must have greatly exceeded reutilization by algae (and bacteria), giving rise to the exceptional enrichment of phosphate measured in several samples at Site A (Fig. 4b). Thomas et al. (1998) observed highly concentrated sea-ice communities in internal voids penetrating perennial sea ice in the Bellingshausen Sea during summer. Supporting our line of arguments, salinity-normalized ammonium and phosphate concentrations exceeding seawater values along with substantial DOM accumulation were interpreted as indication for efficient in situ nutrient regeneration mediated by copepods, which were found in similar numbers as in our study. Unfortunately, DIC and oxygen concentrations were not reported in this study. However, it has to be mentioned that liberation of internal pools can explain the elevated phosphate concentrations only to a certain point. Phosphate concentrations of more than $10 \mu \mathrm{mol} \mathrm{kg} \mathrm{kg}^{-1}$ as found in this study are yet not understood.

In addition, cell mortality and subsequent lysis of polar diatoms can also be induced by a combination of nitrate exhaustion, high $\mathrm{pH}$, strong oxygen oversaturation, and low concentrations of dissolved carbon dioxide (Gleitz et al. 1996b, Peters \& Thomas 1996a). Such conditions may regularly be attained during advanced stages of ice algal blooms when exchange with the surrounding seawater is greatly restricted (Gleitz et al. 1995, 1996a, this study).

It has been shown that small-sized siliceous debris produced by grazing zooplankton experiences significantly higher dissolution rates than intact diatom frus-

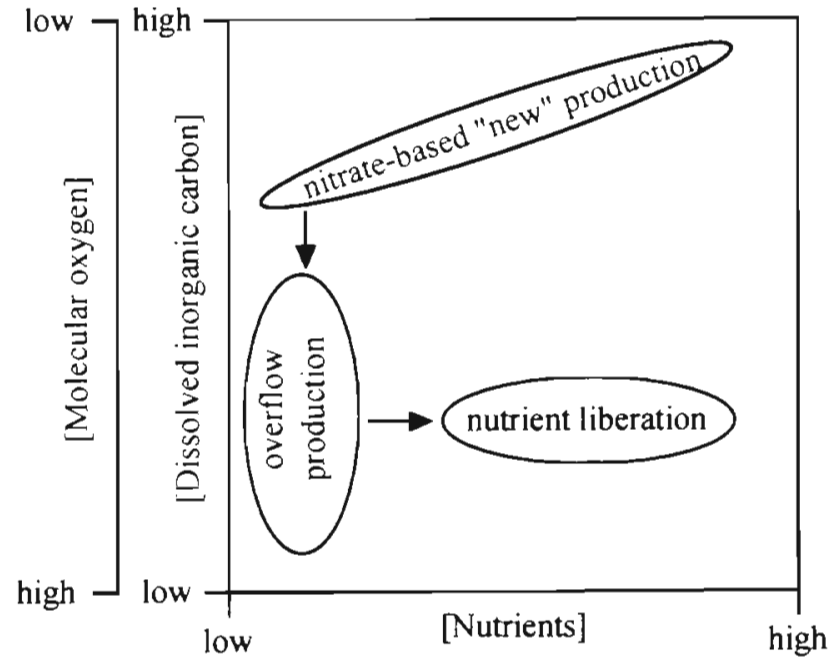

Fig. 8. Hypothetical relationship between molecular oxygen, dissolved inorganic carbon, and nutrient concentrations larbitrary units) in sea-ice ecosystems during different stages of ice algal blooms (for detailed description see text)

tules or biogenic silica enclosed within fecal pellets (Tréguer et al. 1989, Nelson et al. 1991). Additionally, alkalinisation of the medium due to intense primary productivity up to $\mathrm{pH}$ values $>9$ (as present here) will have also enhanced dissolution rates of biogenic silica (Kamatani et al. 1988). However, compared with liberation of phosphate due to disintegration, dissolution of biogenic silica is a slow process and therefore does not lead to elevated silicate concentrations (Fig. 4a). Moreover, silicate is removed continuously when liberated nitrate and phosphate are taken up for cell growth. The main features of the proposed inorganic carbon, oxygen and nutrient relationships proposed here are summarized in Fig. 8.

In conclusion, it is clear that geochemical dynamics in semi-enclosed sea-ice ecosystems are complex, and many of the processes discussed above await further verification. Nevertheless, the concept proposed here highlights the potential importance of several features not adequately accounted for in previous studies. In addition to the alternative pathways of nutrient recycling laid out above, our data and results presented elsewhere indicate high rates of DOM production during advanced stages of ice algal blooms where replenishment of nutrients is restricted. The significance of DOM for ice-based productivity and carbon turnover, however, represents a major unknown in current concepts of sea-ice ecosystem functioning. Altogether, the scenario developed here should help to direct future research to key processes that need to be clarified. In this respect, complete data sets including time-series measurements of all particulate and dissolved organic and inorganic constituents of sea-ice biogeochemical cycles are required. 
Acknowledgements. We thank captain and crew of RV 'Polarstern', as well as pilots and crew of helicopter service Wasserthal, for their excellent service during occupation and breakup of the field camp. We thank $M$. Stürcken-Rodewald for conducting the nutrient determinations, and B. Schneider for carrying out the $\mathrm{C} / \mathrm{N}$ analyses. We thank $\mathrm{V}$. Smetacek for critically reviewing the manuscript; it has also greatly benefited from discussions with $M$. Rutgers van der Loeff, $U$. Riebesell and S. Grossmann. Our research at Drescher Inlet would not have been possible without the logistic support, good humor and friendship of J. Plötz and $\mathrm{H}$. Bornemann. This is AWI publication no. 1515.

\section{LITERATURE CITED}

Ackley SF, Sullivan CW (1994) Physical controls on the development and characteristics of Antarctic sea ice biological communities - a review and synthesis. Deep-Sea Res 41: $1583-1604$

Antia NJ, McAllister CD, Parsons TR, Stephens K, Strickland JDH (1963) Further measurements of primary production using a large-volume plastic sphere. Limnol Oceanogr 8 : 166-183

Arrigo KR, Sullivan CW (1994) A high resolution bio-optical model of microalgal growth: tests using sea-ice algal community time-series data. Limnol Oceanogr 39-3:609-631

Arrigo KR, Robinson DH, Sullivan CW (1993a) A high resolution study of the platelet ice ecosystem in McMurdo Sound, Antarctica: photosynthetic and bio-optical characteristics of a dense microalgal bloom. Mar Ecol Prog Ser 98:173-185

Arrigo KR, Kremer NJ, Sullivan CW (1993b) A simulated Antarctic fast ice ecosystem. J Geophys Res 98-C4: 6929-6946

Arrigo KR, Dieckmann G, Gosselin M, Robinson DH, Fritsen $C H$, Sullivan CW (1995) High resolution study of the platelet ice ecosystem in McMurdo Sound, Antarctica: biomass, nutrient, and production profiles within a dense microalgal bloom. Mar Ecol Prog Ser 127:255-268

Arrigo KR, Worthen DL, Lizotte MP, Dixon P, Dieckmann G (1997) Primary production in Antarctic sea ice. Science 276:394-397

Banse K (1994) Uptake of inorganic carbon and nitrate by marine plankton and the Redfield ratio. Global Biogeochem Cycles 8:81-84

Brewer PG, Goldmann. JC (1.976) Alkalinity changes generated by phytoplankton growth. Limnol Oceanogr 21:108-117

Broecker WS, Peng TH (1982) Tracers in the sea. Columbia University, Palisades, New York

Bunt JS (1964) Primary productivity under sea ice in Antarctic waters. 2. Influence of light and other factors on photosynthetic activities of Antarctic marine microalgae. In: Lee MO (ed) Biology of the Antarctic Seas. American Geophysical Union, Antarctic Research Series 1:27-31

Burkill PH, Edwards ES, Sleigh MA (1995) Microzooplankton and their role in controlling phytoplankton growth in the marginal ice zone of the Bellingshausen Sea. Deep-Sea Res II 42(4-5):277-1290

Butler EI, Corner EDS, Marshall SM (1.969) On the nutrition and metabolism of zooplankton VI. Feeding efficiency of Calanus in terms of nitrogen and phosphorus. J Mar Biol Assoc UK 49:977-1001

Conover RJ, Huntley M (1991) Copepods in ice-covered seas - distribution, adaptations to seasonally limited food, metabolism, growth patterns and life cycle strategies in polar seas. J Mar Syst 2:1-41
Cota GF (1985) Photoadaptation of high Arctic ice algae Nature 315:219-222

Dahms HU, Bergmans M. Schminke HK (1990) Distribution and adaptations of sea ice inhabiting Harpacticoida (Crustacea, Copepoda) of the Weddell Sea (Antarctica). PSZN I Mar Ecol 11(3):207-226

de Baar HJW, de Jong JTM, Bakker DCE, Löscher BM, Veth C. Bathmann U, Smetacek V (1995) Importance of iron for plankton blooms and carbon dioxide drawdown in the Southern Ocean. Nature 373:412-415

Dieckmann GS, Lange MA, Ackley SF, Jennings JC Jr (1991) The nutrient status in sea ice of the Weddell Sea during winter: effects of sea ice texture and algae. Polar Biol 11 $449-456$

Dieckmann GS, Arrigo K, Sullivan CW (1992) A high-resolution sampler for nutrient and chlorophyll a profiles of the sea ice platelet layer and underlying water column below fast ice in polar oceans: preliminary results. Mar Ecol Prog Ser 80:291-300

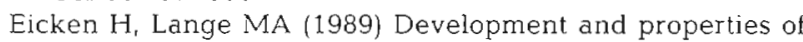
sea ice in the coastal regime of the southeastern Weddell Sea. J Geophys Res 94-C6:8193-8206

Evans CA, O'Reilly JE (1983) A handbook for measurement of chlorophyll $a$ in netplankton and nannoplankton. National Oceanographic and Atmospheric Administration, Highlands, NJ

Fagerbakke KM, Heldal M, Norland S (1996) Content of carbon, nitrogen, sulfur and phosphorus in native aquatic and cultured bacteria. Aquat Microb Ecol 10:15-27

Fahl K, Kattmer G (1993) Lipid content and fatty acid composition of algal communities in sea-ice and water from the Weddell Sea (Antarctica). Polar Biol 1.3:405-409

Falkowski PG, Woodhead AD (eds) (1992) Primary productivity and biogeochemical cycles in the sea. Environmental Science Research, Vol 43, Plenum Press, New York

Fritsen CH, Lytle VI, Ackley SF, Sullivan CW (1994) Autumn bloom of Antarctic pack-ice algae. Science 266:782-784

Garrison DL (1991) Antarctic sea ice biota. Am Zool 31:17-33

Garrison DL, Close AR, Gordon LI (1990) Nutrient concentrations in Antarctic pack ice during the austral winter. In: Ackley SF, Weeks WF (eds) Sea ice properties and processes. US Army Corps of Engineers, Hanover, NH, CRREL Monograph 90-1, p 35-40

Gleitz M. Rutgers $\vee$ d Loeff $M$, Thomas DN, Dieckmann GS, Millero FJ (1995) Comparison of summer and winter inorganic carbon, oxygen and nutrient concentrations in Antarctic sea ice brine. Mar Chem 51:81-91

Gleitz M., Grossmann S, Scharek R, Smetacek V (1996a) Ecology of diatom and bacterial assemblages in water associated with melting summer sea ice in the Weddell Sea, Antarctica. Antarct Sci 8-2:135-146

Gleitz M, Kukert H. Riebesell U, Dieckmann GS (1996b) Carbon acquisition and growth of Antarctic sea ice diatoms in closed bottle incubations. Mar Ecol Prog Ser 135:169-177

Grasshoff K (1983) Determination of oxygen. In: Grasshoff K; Ehrhardt $M$ Kremling $K$ (eds) Methods of seawater analysis. Verlag Chemie, Weinheim, p 61-72

Grossmann S (1994) Bacterial activity in sea ice and open water of the Weddell Sea, Antarctica: a microradiographic study. Microb Ecol 28:1-18

Grossmann S, Lochte K, Scharek R (1996) Algal and bacterial processes in platelet ice during late austral summer. Polar Biol 16:623-633

Ikeda T, Mitchell AW (1982) Oxygen uptake, ammonium excretion and phosphate excretion by krill and other Antarctic zooplankton in relation to their body size and chemical composition. Mar Biol 71:283-298 
Jacques G (1983) Some ecophysiological aspects of the Antarctic phytoplankton. Polar Biol 2:27-33

Jennings JC Jr, Gordon LI, Nelson DM (1984) Nutrient depletion indicates high primary productivity in the Weddell Sea. Nature 309:51-54

Kamatani A, Nobuhiko E, Tréguer P (1988) The dissolution kinetics of diatom ooze from the Antarctic area. Deep-Sea Res 35(7): 1195-1203

Kirkwood DS (1992) Stability of solutions of nutrient salts during storage. Mar Chem 38:151-164

Kurbjeweit F, Gradinger R, Weissenberger J (1993) The life cycle of Stephos longipes-an example for cryopelagic coupling in the Weddell Sea (Antarctica). Mar Ecol Prog Ser $98: 255-262$

Larsson U, Hagström A (1982) Fractionated phytoplankton primary production, exudate release and bacterial production in a Baltic eutrophication gradient. Mar Biol 67-1. $57-70$

Laws EA (1991) Photosynthetic quotients, new production and net community production in the open ocean. DeepSea Res 38-1:143-167

Le Borgne $R$ (1986) The release of soluble end products of metabolism. In: Corner EDS, O'Hara SCM (eds) The biological chemistry of marine copepods. Clarendon Press, Oxford, p 109-164

Legendre L, Ackley SF, Dieckmann GS, Gulliksen B, Horner R, Hoshiai T, Melnikov IA, Reeburgh WS, Spindler M, Sullivan CW (1992) Ecology of sea ice biota. 2. Global significance. Polar Biol 12:429-444

Lewin JC (1961) The dissolution of silica from diatom walls. Geochim Cosmochim Acta 21:182-198

Lignell R (1990) Algal exudation and its relation to bacterial production during vernal phytoplankton bloom. Arch Hydrobiol Beih 34:53-59

McAllister CD, Parsons TR, Stephens K, Strickland JDH (1961) Measurements of primary production in coastal seawater using a large-volume plastic sphere. Limnol Oceanogr 6:237-258

Mehrbach C, Culberson $\mathrm{CH}$, Hawley JE, Pytkowicz RM (1973) Measurement of the apparent dissociation constant of carbonic acid in seawater at atmospheric pressure. Limnol Oceanograph 18-6:897-907

Nelson DM, Tréguer P (1992) Role of silicon as a limiting nutrient to Antarctic diatoms: evidence from kinetic studies in the Ross Sea ice-edge zone. Mar Ecol Prog Ser 80: $255-264$

Nelson DM, Ahern JA, Herlihy LJ (1991) Cycling of biogenic silica within the upper water column of the Ross Sea. Mar Chem 35:461-476

O'Connors HB, Small LF, Donaghay PL (1976) Particle-size modification by two size classes of the estuarine copepod Acartia clausi. Limnol Oceanogr 21-2:300-308

Palmisano AC, Garrison DL (1993) Microorganisms in Antarctic sea ice. In: Friedman El (ed) Antarctic microbiology, Wiley-Liss, New York, p 167-218

Peters E, Thomas DN (1996a) Prolonged nitrate exhaustion

Editorial responsibility: Otto Kinne (Editor),

Oldendorf/Luhe, Germany and diatom mortality: a comparison of polar and temperate Thalassiosira species. J Plankton Res 18-6:953-968

Peters E, Thomas DN (1996b) Prolonged darkness and diatom mortality I: marine Antarctic species. J Exp Mar Biol Ecol $207: 25-41$

Priscu JC, Sullivan CW (1998) Nitrogen metabolism in Antarctic fast-ice microalgal assemblages. In: Lizotte MP, Arrigo KR (eds) Antarctic sea ice biological processes, American Geophysical Union, Antarctic Research Series $73: 147-160$

Redfield AC (1958) The biological control of chemical factors in the environment. A.m Scient 46-3:205-221

Roy S, Harris RP. Poulet SA (1989) Inefficient feeding by Calanus helgolandicus and Temora longicornis on Coscinodiscus wailesii: quantitative estimation using chlorophyll-type pigments and effects on dissolved free amino acids. Mar Ecol Prog Ser 52:145-153

Scharek R, Smetacek V, Fahrbach E, Gordon LI, Rohardt G, Moore S (1994) The transition from winter to early spring in the eastern Weddell Sea, Antarctica: plankton biomass and composition in relation to hydrography and nutrients. Deep-Sea Res 1 41-8:1231-1250

Schnack-Schiel SB, Thomas D, Dieckmann GS, Eicken $\mathrm{H}_{\text {, }}$ Gradinger R, Spindler $M$, Weissenberger J, Mizdalski E, Beyer K (1995) Life cycle strategy of the Antarctic calanoid copepod Stephos longipes. Prog Oceanogr 36 $45-75$

Smetacek V, Scharek R, Gordon LI, Eicken H, Fahrbach E, Rohardt G, Moore S (1992) Early spring phytoplankton blooms in ice platelet layers of the southern Weddell Sea, Antarctica. Deep-Sea Res 39-2:153-168

Smith REH, Harrison WG, Harris LR, Herman AW (1989) Vertical fine structure of particulate matter and nutrients in sea ice of the High Arctic. Can J Fish Aquat Sci 47: $1348-1355$

Spies A, Brockmann UH, Kattner G (1988) Nutrient regimes in the marginal ice zone of the Greenland Sea in summer Mar Ecol Prog Ser 47:195-204

Tanimura A, Hoshiai T, Fukuchi M (1996) The life cycle strategy of the ice-associated copepod Paralabidocera antarctica (Calanoida, Copepoda), at Syowa Station, Antarctica. Antarct Sci 8-3:257-266

Thomas DN, Lara RJ, Eicken H, Kattner G, Skoog A (1995) Dissolved organic matter in Arctic multi-year sea ice during winter: major components and relationship to ice characteristics. Polar Biol 15:477-483

Thomas DN, Lara RJ, Haas C, Schnack-Schiel SB, Dieckmann GS, Kattner G, Nöthig EM, Mizdalski E. (1998) Biological soup within decying summer sea ice in the Amundsen Sea, Antarctic. In: Lizotte MP, Arrigo KR (eds) Antarctic sea ice biological processes. American Geophysical Union, Antarctic Research Series 73:161-171

Tréguer P, Kamatani A, Gueneley S, Quéguiner B (1989) Kinetics of dissolution of Antarctic diatom frustules and the biogeochemical cycle of silicon in the Southern Ocean. Polar Biol 9:397-403

Submitted: January 1, 1998; Accepted: October 20, 1998 Proofs received from author(s): January 20,1999 